\title{
镁质闪石拓扑交生的高分辨电镜研究
}

作者于 1991 年 ${ }^{[1]}$, 报道了在成分上与镁 闪石和直闪石相当的龙泉镁质闪石系由单斜 和 正交两种闪石交生而成的 CTEM 研究 成果. 本文是对这一矿物的高分辨电镜研究 结果的报道.

镁质闪石的晶格条纹象显示，交生两相 的宽度变化不定. 其中单斜闪石相的宽度既 有 $0.9 \mathrm{~nm}$ 偶数倍的,也有 $0.9 \mathrm{~nm}$ 奇数倍的; 在直闪石片晶中, 还掺杂着宽度为 $0.45 \mathrm{~nm}$ 奇数倍的单斜闪石域. 体现了相邻 $\mathrm{Si}-\mathrm{O}$ 回 面体双链带堆垛的无序性, 这与在选区衍射 花样上见到沿 $a^{*}$ 轴方向出现衍射条纹的现 象相符. 交生体中, 单斜闪石域宽度的上述 变, 化可以确证交生体中单斜闪石不是由 直闪石转变而来, 相反, 却可证明直闪石系 由单斜的镁闪石转变而成. 因为直闪石晶 体结构中, 单位晶胞沿 $a$ 轴由 4 个 $0.45 \mathrm{~nm}$ 窥度的板片组成。如果单斜闪石系由直闪石 转变而来, 则在交生体中, 它的宽度应为 0.9 $\mathrm{nm}$ 的偶数倍. 不难理解, 宽度为 $0.9 \mathrm{~nm}$ 奇数 倍的单斜闪石域的出现排除了它由直闪石转 变而来的可能性. 而在直闪石中混杂的宽度 为 $0.45 \mathrm{rm}$ 奇数倍的单斜板片也证明, 这些 板片是单斜闪石向直闪石转变中“错乱”的部 分.

直闪石和镁闪石晶体结构的不 同在于: 从 $a$ 轴看,八面体歪斜方向的不同,也可以看 成四面体双链带位移矢量符号的不同. 由于 单斜闪石向直闪石转变中, 沿 $c$ 轴看, 两端的
八面体歪斜发生“错乱”，因而导致晶体中出 现缺陷.作者从结构条纹象观察到的缺陷是: 一端的八面体歪斜方向为 ++--++-$--++--(++--$ 为直闪石的八面歪 斜形式); 另一端则为 ++--++---+ ++- . 这种错乱的结果引起缺陷两 侧 的正常的直闪石晶胞沿 $c$ 轴方向产生约 $C_{0} / 3$ 的位移.

除上述交生现象外，龙泉闪石中还常见 䥻质闪石的出溶片晶.

基于以上诸事实,作者相信, 初始结晶的 龙泉闪石中含有一定量的钙. 含有䥻的闪石 以 $C 2 / \mathrm{m}$ 结构为稳定 ${ }^{[2]}$. 因此, 这种初始的 闪石为单斜闪石. 在冷却中, 䥻以透内石或 阳起石的形式出溶. 这一出溶作用造成在原 来闪石晶体中局部贫钙．贫钙区内的闪石由 $C 2 / \mathrm{m}$ 结构 (镁闪石) 向 Pnma 结构 (直闪 石）转变. 由于晶体处于冷却较快的地质条 件中，因而这种转变不可能彻底，从而形成 一种直闪石和镁闪石的无序取向连生.

\section{参考 献}

[1] 薛纪越等,科学通报, $1991,36(6): 443-446$.

[2] Ross, M. et al., Science, 1968, 159:1099-1102.

\section{薛纪越马军}

(南京大学地球科学系,南京 210008)

张富生于峰

（南京大学现代分析中心，（南京大学㒋体物理间家重 南京 210008）点实验空, 南京 210008) 